\title{
Weed Control Strips Influences on the Rubber Tree Growth
}

\author{
Caio Doria Guzzo', Leonardo B. de Carvalho², Pedro Luis da C. A. Alves ${ }^{1}$, \\ Elaine Cristine Piffer Gonçalves ${ }^{3}$, Paulo F. Giancotti ${ }^{1}$ \\ ${ }^{1}$ UNESP, Faculdade de Ciências Agrárias e Veterinárias, Jaboticabal, Brazil \\ ${ }^{2}$ UDESC, Universidade do Estado de Santa Catarina, Lages, Brazil \\ ${ }^{3}$ APTA, Agência Paulista de Tecnologia dos Agronegócios, Colina, Brazil \\ Email: caio.guzzo@gmail.com
}

Received 11 December 2013; revised 22 February 2014; accepted 7 March 2014

Copyright (C) 2014 by authors and Scientific Research Publishing Inc.

This work is licensed under the Creative Commons Attribution International License (CC BY).

http://creativecommons.org/licenses/by/4.0/

(c) (i) Open Access

\begin{abstract}
Hevea brasiliensis (rubber tree) is the most widely cultivated tree species for producing natural rubber latex whose productivity can be reduced by weeds. Field experiment was carried out during two years to evaluate the growth of rubber tree plants submitted to different weed control strips (0-weed-free, $50,100,150,200,250,300,350$, and 400 -(weedy $\mathrm{cm})$ and to determine the critical width of weed control strip during the establishment of rubber tree plantation. Weed community was composed mainly by Urochloa decumbens $(90 \%)$. The width of the weed control strip influenced on the initial plant growth of rubber trees, reducing the plant height, stem diameter, leaf area, and aboveground dry mass accumulation. In consequence, crop plantation was affected by the width of weed control. The critical width of the weed control strip for establishment of a rubber tree plantation was within $100 \mathrm{~cm}$.
\end{abstract}

\section{Keywords}

Hevea brasiliensis; Urochloa decumbens; Weed Control; Weed Interference

\section{Introduction}

Hevea brasiliensis (Willd. ex. Adr. De Juss.) Muell.-Arg., commonly known as Brazilian rubber tree, is the most widely cultivated tree species for producing natural rubber latex. The tree is a perennial cross-pollinating and monoecious plant of the family Euphorbiaceae [1], native to South America and widely cultivated worldwide, mainly in the South East Asia [2]. Brazil produces 100 million tons of latex a year, being the São Paulo State the most important producer responsible for $55 \%$ of the Brazilian rubber production, totalizing approximately 
75,000 ton of rubber per year [3]. Brazil is not self-sufficient in rubber production so that any factor affecting latex extraction can be very deleterious to rubber production. Latex production by rubber trees can be affected by biotic factors such as microorganisms causing plant diseases and other factors increasing the timing to plants reach the maturity for latex extraction [4]. In this way, weed interference (resulted of the weed competition for light, $\mathrm{CO}_{2}$, water, nutrients, and space as well as of the allelopathic effects of some weed species) is an important issue reducing plant growth and, in consequence, increasing the timing for plant maturity [5] [6]. Weed management during the establishment of commercial tree plantations is a major factor that contributes to improvement of the final yield [7]-[9]. Development of a sound vegetation management strategy requires a definite and sequential plan of action [9]. A good understanding of the basic criteria involved in weed-tree interactions, growth-limiting factors, the minimum tolerable weed thresholds and an understanding of the best parameters of measurement are needed to delineate an appropriate management approach [10]. Researchers have demonstrated that the width of weed control strips reflected in the growth of some trees, such as Coffea arabica [11]-[13] and Eucaliptus spp. [7] [9] [14], but the effect depends on several factors, including weed composition, crop species, and the availability of environmental resources. In function of the importance and the lack of information on weed interference in rubber tree plantation, we performed this research aiming 1) to evaluate the growth of rubber tree plants submitted to different weed control strips and 2) to determine the critical width of weed control strip during the establishment of rubber tree plantation.

\section{Matherials and Methods}

\subsection{Site Description}

The field trial was carried out from December 2008 to December 2010, in Southeast of Brazil, at $20^{\circ} 43^{\prime} 05^{\prime \prime} \mathrm{S}$ and $42^{\circ} 32^{\prime} 38^{\prime \prime} \mathrm{W}$ Gr. and an altitude of $589 \mathrm{~m}$ asl. The soil is classified as an Oxissol clay textured. The original vegetation was a degraded pasture dominated by Urochloa decumbens (Stapf.) Webster (syn. Brachiaria decumbens Stapf.) (up to 90\% groundcover) and some weed species such as Sida spp., Portulaca oleracea L., and others. The local climate is tropical of altitude with a dry season (Köppen-Geiger classification is Aw). Average historical daily maximum and minimum temperatures are $30.8^{\circ} \mathrm{C}$ and $12.8^{\circ} \mathrm{C}$, respectively, and mean annual rainfall was $1408.9 \mathrm{~mm}$, being concentrated from October to March.

\subsection{Site Preparation and Plantation}

Previously to crop plantation, site vegetation was desiccated with glyphosate at $1.08 \mathrm{~kg} \cdot \mathrm{ae}^{\mathrm{h}} \mathrm{ha}^{-1}$. A week after desiccation, land was tillage by mould board plough, disc plough and disc harrow, in sequence. Crop was planted in December 20, 2008, using rubber tree clone RRIM 600 seedlings obtained by normal-T-budding. Soil fertilization was performed using $150 \mathrm{~g}$ de single superphosphate at the moment of seedling plantation and four more monthly fertilizations were made afterwards, using 30, 40, 50 and $60 \mathrm{~g}$ of ammonium sulfate per plant. Water was also supplied during the first year of experimental conduction.

\subsection{Experimental Design and Treatments}

Experimental plots constituted of four rows spaced by $8 \mathrm{~m}$ with four plants spaced by $2.5 \mathrm{~m}$. Treatments consisted of different weed control strips from the row into the middle of the inter-row. The widths of the weed control strips used were 0 (weed-free), 50, 100, 150, 200, 250, 300, 350, and 400 (weedy) cm. The weed control strips were monthly established by glyphosate applications at $1.08 \mathrm{~kg} \cdot \mathrm{ae}^{\mathrm{h}} \mathrm{ha}^{-1}$, complementing with hand-weeding if necessary, from planting up to 720 days (2 years) after planting. Treatments were arranged in a randomized block design with three replicates.

\subsection{Measurements}

All measurements were performed within the area of the two central rows. Stem diameter (digital paquimeter) and plant height (yardstick) were monthly measured from 60 up to 360 days after planting (DAP), during the first-year-investigation, and at 420, 480, 540, and 720 DAP, during the second-year-investigation. At 360 DAP, leaf area and aboveground dry mass were also evaluated. One plant per each replicate was cut off close to the ground for counting the number of leaves and determination of the leaf area (Li-Cor, Li-3000 A, USA). Above- 
ground material was dried to constant weight in a forced air-convection oven at $70^{\circ} \mathrm{C}$, and following weighted.

\subsection{Data Analysis}

The relative growth rate (RGR) was calculated based on both plant height and stem diameter data, according to the equation:

$$
R G R=(V 2-V 1) /(T 2-T 1),
$$

where $R G R$ is the relative growth rate of plant height or stem diameter; $V 1$ and $V 2$ are the values of plant height or stem diameter at $T 1$ and $T 2$, respectively; $T 1$ and $T 2$ are consecutive times of evaluation. After that, average $R G R$ was calculated among all evaluations, including first- and second-year-investigation.

Data of plant height, stem diameter, leaf area, and aboveground dry mass, at $360 \mathrm{DAP}$, were fitted to a non-linear, exponential regression model:

$$
y=y 0+a\left(1-\mathrm{e}^{-b x}\right),
$$

where $y$ is the value on a rubber three characteristic, $y 0$ is the coefficient corresponding to the lower value of $y, a$ is the coefficient corresponding to the difference between the minimum and maximum value of $y, b$ is the slope of the line, and $x$ is the number of days.

Data of plant height and stem diameter, at 720 DAP, were fitted to a non-linear, logistic regression model:

$$
y=y 0+a /\left[1+(x / x 0)^{b}\right],
$$

where $y$ is the value on a rubber three characteristic, $y 0$ is the coefficient corresponding to the lower asymptote, $a$ is the coefficient corresponding to the difference between the lower and upper asymptotes, $b$ is the slope of the line, $x 0$ is the point of inflection halfway between the upper and lower asymptotes, and $x$ is the number of days.

In addition, the interval of confidence of each logistic equation parameter was determined by using Statistica software (StatSoft, version 8.0, USA). All regression analyses were performed using SigmaPlot software (Systat, version 10.0, USA). Moreover, the residual normality and constant variance of the adjusted equation was tested by using SigmaPlot software (Systat, version 10.0, USA). SigmaPlot uses the Kolmogorov-Smirnov test to test for a normally distributed population and tests for constant variance by computing the Spearman rank correlation between the absolute values of the residuals and the observed value of the dependent variable.

\section{Results and Discussion}

\subsection{Vegetation Composition}

In the first-year-investigation, four monocotyledon species such as U. decumbens, Cyperus rotundus L., Eleusine indica (L.) Gaertn. and Megathyrsus maximus (Jacq.) B. K. Simon \& S. W. L. Jacobs (syn. Panicum maximum Jacq.), and at least nine eudicotyledon species such as Amaranthus spp., P. oleracea, Indigofera hirsuta L., Ipomoea spp., Malva spp., Mimosa pudica L., Richardia brasiliensis Gomes, Sida spp. and Spermacoce latifolia Aubl. were found infesting rubber tree plantation. Among them, $U$. decumbens showed the highest relative importance (over 90\%), mainly after 90 DAP while $P$. oleracea and Sida spp. were also important species up to 90 DAP (data not shown). As the experimental field was a degraded pasture of $U$. decumbens species, it was expected that this plant was the dominant species.

Grasses and herbaceous broad-leaved weed species are widely found during plantation establishment and constitute a major impediment to successful early growth and development of tree crops [15]-[19]. Interference of weeds can range from significant suppression of crop growth to widespread mortality [19]. Productivity subsequently may be reduced throughout the rotation [20]. The benefits from using fertilizer and genetically improved seedlings can often be reduced [21] [22]. Furthermore, stress caused by weed interference can increase susceptibility to attack from pests and diseases [23].

Rubber tree plantation is commonly established on degraded pastures of grass species, such as $U$. decumbens, $U$. brizantha, P. maximum, and others. These species can show different potential of infestation and competition capacity on rubber tree plants. In Brazil, $U$. decumbens is one of the most common species present in degraded pastures. This species has been reported causing growth reduction on tree crops such as Coffee spp. [11] [24] 
[25] and Eucalyptus spp. [14] [26]. So, U. decumbens is a potential species infesting and influencing the growth of rubber tree plants under establishment in field conditions.

\subsection{Rubber Tree Growth}

Analyzing the rubber tree growth within each weed control strip during 720 DAP, the best adjusted equation was a logistic model, showing a high significance, normal distribution of residuals, and constant variance of residuals (Tables 1 and 2), being well-appropriated to describe the plant behavior and satisfying statistical conditions. This analysis shows the accumulated plant growth within each weed control strip during the whole experimental period. For both plant height and stem diameter, the interval of confidence of the equation parameters $b$, $x 0$, and $y 0$ was correspondent to all weed control strips, indicating no significant difference. However, the interval of confidence of the equation parameter $a$ was not correspondent to all weed control strips, being also distinct for plant height and stem diameter.

For plant height, the interval of confidence of the parameter $a$ in the weedy condition was not correspondent to any weed control strip. For stem diameter, the interval of confidence of the parameter a in the weedy situation and weed control strips of $50 \mathrm{~cm}$ and $100 \mathrm{~cm}$ was correspondent, but differing of weed control strips of 150, 200, $250,300,350$, and $400 \mathrm{~cm}$. The parameter a indicates the difference between minimum and maximum values of the growth characteristics, so that higher a values shows a better or a greater plant growth of the rubber trees, as observed when weeds were controlled in larger widths. In this sense, analyzing the plant growth within each weed control strip, the weed control should be performed within strips of $50 \mathrm{~cm}$ and $150 \mathrm{~cm}$ for plant height and stem diameter, respectively.

Analyzing the RGR during 720 DAP, in function of crescent weed control strips, the best adjusted equation was an exponential rising to maximum model, showing a high significance, normal distribution of residuals, and constant variance of residuals (Figure 1 and Table 3), being well-appropriated to describe the plant behavior and satisfying statistical conditions. So, we observed that RGR increased when weed control strips was extended, reaching a maximum value and then keeping constant. Very slightly differences on plant growth occurred within a range of weed control strips from 50 up to $150 \mathrm{~cm}$, for both plant height and stem diameter, according to the adjusted regressions. In this sense, the results are in accordance with those ones presented above, so that the weed control should be performed within a range strip between $50 \mathrm{~cm}$ and $150 \mathrm{~cm}$.

Now, analyzing the growth pattern of rubber trees specifically at 360 DAP and 720 DAP, in function of crescent weed control strips, the best adjusted equation was also an exponential rising to maximum model, showing a high significance, normal distribution of residuals, and constant variance of residuals (Figures 2, 3 and Table 3), being well-appropriated to describe the plant behavior and satisfying statistical conditions. We observed that all the growth characteristics increased when weed control strips was extended, reaching a maximum value and then keeping constant, as observed by RGR. In addition, at the ending of 360 DAP and 720 DAP, any weed control strip allowed rubber trees to grow more than in a total weedy situation, independently of the strip width.

In spite of that, the determination of the strip width required to an effective weed control without permitting a significant plant growth reduction was dependent on growth characteristics evaluated. In this sense, at the ending of $360 \mathrm{DAP}$, the best weed control strip for plant height and stem diameter development was within $150 \mathrm{~cm}$; however the best strip for leaf area and aboveground dry mass development was within $50 \mathrm{~cm}$ and $200 \mathrm{~cm}$, respectively (Figure 2). In general, similar results were observed at the ending of 720 DAT, however the best strip for plant height and stem diameter development was within $100 \mathrm{~cm}$ (Figure 3), indicating a slight growth recovery of plants growing under weed control strips within $50 \mathrm{~cm}$ and $100 \mathrm{~cm}$. So, we suppose that weed control within a strip of $100 \mathrm{~cm}$ is sufficient to prevent weed interference on the establishment of a rubber tree plantation.

A reduction in the availability of moisture and nutrients leads to reduced tree growth and survival [27]. In our study, rubber trees in the weedy plots suffered the most from weed competition, exhibiting comparatively poor growth and stem diameter reduction [9]. That reduction also affected the development of the leaf area and the aboveground dry mass accumulation, impacting negatively on the initial growth and establishment of rubber trees in the two years after plantation.

No studies were found on rubber trees, but in South Africa, eucalyptus crown growth of $10 \mathrm{~cm}$ can be attained in 41 days with 20\% weeding or in 66 days with $0 \%$ weeding [28]. Little et al. [29] used the tree crown diameter as an indication of tree performance. They observed a distinct exponential increase in median crown diameter 
Table 1. Statistical analysis of the plant height data of rubber tree plants growing under different weed control strips during two years. Brazil, 2011.

\begin{tabular}{|c|c|c|c|c|c|}
\hline \multirow{4}{*}{ Strip (cm) } & \multirow{4}{*}{ Parameter } & \multirow{4}{*}{ Coef } & \multirow{4}{*}{$\mathrm{t}$} & \multirow{4}{*}{ IC (5\%) } & ${ }^{1}$ Adj $\mathrm{R}^{2}$ \\
\hline & & & & & ${ }^{2} \mathrm{~F}$ \\
\hline & & & & & ${ }^{3}$ Norm (p) \\
\hline & & & & & ${ }^{4}$ Const Var (p) \\
\hline \multirow{4}{*}{0} & $a$ & 199 & 26 & 181.7:215.3 & ${ }^{1} 0.99$ \\
\hline & $b$ & -7.1 & -9.5 & $-8.8:-5.5$ & ${ }^{2} 521.6$ \\
\hline & $x 0$ & 365 & 56 & $350.6: 379.4$ & ${ }^{3} 0.716$ \\
\hline & $y 0$ & 41.1 & 14 & $34.4: 47.7$ & ${ }^{4} 0.381$ \\
\hline \multirow{4}{*}{50} & $a$ & 258 & 18 & 226.1:290.0 & ${ }^{1} 0.99$ \\
\hline & $b$ & -5.3 & -7.7 & $-6.8:-3.8$ & ${ }^{2} 325.8$ \\
\hline & $x 0$ & 352 & 34 & 329.2:374.4 & ${ }^{3} 0.868$ \\
\hline & $y 0$ & 53.6 & 9.9 & $41.7: 65.4$ & ${ }^{4} 0.073$ \\
\hline \multirow{4}{*}{100} & $a$ & 263 & 18 & 231.3:295.6 & ${ }^{1} 0.98$ \\
\hline & $b$ & -6.7 & -6.6 & $-9.0:-4.5$ & ${ }^{2} 254.4$ \\
\hline & $x 0$ & 352 & 38 & 331.4:372.2 & ${ }^{3} 0.659$ \\
\hline & $y 0$ & 60.2 & 10 & 46.9:73.4 & ${ }^{4} 0.883$ \\
\hline \multirow{4}{*}{150} & $a$ & 371 & 11 & 294.9:447.9 & ${ }^{1} 0.97$ \\
\hline & $b$ & -3.9 & -5.9 & $-5.5:-2.5$ & ${ }^{2} 199.2$ \\
\hline & $x 0$ & 366 & 18 & 321.5:409.6 & ${ }^{3} 0.555$ \\
\hline & $y 0$ & 55.9 & 5.4 & $33.2: 78.6$ & ${ }^{4} 0.803$ \\
\hline \multirow{4}{*}{200} & $a$ & 314 & 12 & 254.7:373.9 & ${ }^{1} 0.97$ \\
\hline & $b$ & -4.9 & -5.3 & $-7.0:-2.9$ & ${ }^{2} 154.4$ \\
\hline & $x 0$ & 356 & 22 & $320.0: 391.8$ & ${ }^{3} 0.619$ \\
\hline & $y 0$ & 64.8 & 6.8 & $43.7: 85.8$ & ${ }^{4} 0.676$ \\
\hline \multirow{4}{*}{250} & $a$ & 304 & 12 & 245.6:361.8 & ${ }^{1} 0.97$ \\
\hline & $b$ & -4.8 & -5.3 & $-6.8:-2.8$ & ${ }^{2} 153.5$ \\
\hline & $x 0$ & 349 & 21 & 313.2:385.1 & ${ }^{3} 0.933$ \\
\hline & $y 0$ & 61.5 & 6.4 & $40.5: 82.4$ & ${ }^{4} 0.883$ \\
\hline \multirow{4}{*}{300} & $a$ & 326 & 14 & 276.0:376.1 & ${ }^{1} 0.98$ \\
\hline & $b$ & -5.8 & -5.9 & $-7.9:-3.6$ & ${ }^{2} 191.8$ \\
\hline & $x 0$ & 355 & 29 & 327.6:382.4 & ${ }^{3} 0.84$ \\
\hline & $y 0$ & 57 & 6.6 & $37.9: 76.0$ & ${ }^{4} 0.095$ \\
\hline \multirow{4}{*}{350} & $a$ & 330 & 14 & 278.9:380.3 & ${ }^{1} 0.98$ \\
\hline & $b$ & -5.7 & -5.8 & $-7.9:-3.6$ & ${ }^{2} 189$ \\
\hline & $x 0$ & 351 & 28 & 323.8:378.2 & ${ }^{3} 0.595$ \\
\hline & $y 0$ & 56.4 & 6.3 & $36.7: 76.1$ & ${ }^{4} 0.743$ \\
\hline \multirow{4}{*}{400} & $a$ & 333 & 12 & 269.7:396.5 & ${ }^{1} 0.97$ \\
\hline & $b$ & -5.0 & -5.4 & $-7.1:-2.9$ & ${ }^{2} 153.9$ \\
\hline & $x 0$ & 362 & 22 & 325.2:398.1 & ${ }^{3} 0.929$ \\
\hline & $y 0$ & 57.4 & 5.8 & $35.5: 79.2$ & ${ }^{4} 0.293$ \\
\hline
\end{tabular}

${ }^{*} p<0.001$. 
Table 2. Statistical analysis of the stem diameter data of rubber tree plants growing under different weed control strips during two years. Brazil, 2011.

\begin{tabular}{|c|c|c|c|c|c|}
\hline \multirow{4}{*}{ Strip (cm) } & \multirow{4}{*}{ Parameter } & \multirow{4}{*}{ Coef } & \multirow{4}{*}{$\mathrm{t}$} & \multirow{4}{*}{ IC (5\%) } & ${ }^{1}$ Adj R ${ }^{2}$ \\
\hline & & & & & ${ }^{2} \mathrm{~F}$ \\
\hline & & & & & ${ }^{3}$ Norm (p) \\
\hline & & & & & ${ }^{4}$ Const Var (p) \\
\hline \multirow{4}{*}{0} & $a$ & 2.2 & 10 & $1.9: 2.5$ & ${ }^{1} 0.96$ \\
\hline & $b$ & -5.7 & -4.7 & $-8.3:-3.1$ & ${ }^{2} 113$ \\
\hline & $x 0$ & 392 & 20 & 349.4:433.8 & ${ }^{3} 0.079$ \\
\hline & $y 0$ & 0.6 & 8.3 & $0.4: 0.7$ & ${ }^{4} 0.176$ \\
\hline \multirow{4}{*}{50} & $a$ & 2.6 & 17 & $2.2: 2.9$ & ${ }^{1} 0.98$ \\
\hline & $b$ & -6.5 & -6.2 & $-8.8:-4.2$ & ${ }^{2} 220.9$ \\
\hline & $x 0$ & 354 & 34 & 331.1:376.6 & ${ }^{3} 0.97$ \\
\hline & $y 0$ & 0.7 & 12 & $0.6: 0.9$ & ${ }^{4} 0.449$ \\
\hline \multirow{4}{*}{100} & $a$ & 2.7 & 18 & 2.4:3.0 & ${ }^{1} 0.98$ \\
\hline & $b$ & -9 & -5.5 & $-12.6:-5.4$ & ${ }^{2} 204.8$ \\
\hline & $x 0$ & 361 & 42 & 341.8:379.5 & ${ }^{3} 0.981$ \\
\hline & $y 0$ & 0.8 & 13 & $0.7: 1.0$ & ${ }^{4} 0.549$ \\
\hline \multirow{4}{*}{150} & $a$ & 3.7 & 16 & $3.2: 4.2$ & ${ }^{1} 0.98$ \\
\hline & $b$ & -5.5 & -7.2 & $-7.2:-3.8$ & ${ }^{2} 269.8$ \\
\hline & $x 0$ & 372 & 31 & 345.8:398.4 & ${ }^{3} 0.802$ \\
\hline & $y 0$ & 0.9 & 11 & $0.7: 1.1$ & ${ }^{4} 0.549$ \\
\hline \multirow{4}{*}{200} & $a$ & 3.3 & 13 & $2.7: 3.8$ & ${ }^{1} 0.97$ \\
\hline & $b$ & -6.9 & -5.0 & $-9.9:-3.9$ & ${ }^{2} 142.1$ \\
\hline & $x 0$ & 372 & 28 & $342.5: 400.8$ & ${ }^{3} 0.97$ \\
\hline & $y 0$ & 0.9 & 9.9 & $0.7: 1.1$ & ${ }^{4} 0.23$ \\
\hline \multirow{4}{*}{250} & $a$ & 3.1 & 14 & 2.6:3.7 & ${ }^{1} 0.97$ \\
\hline & $b$ & -6.2 & -5.5 & $-8.7:-3.7$ & ${ }^{2} 166.2$ \\
\hline & $x 0$ & 366 & 13 & 336.8:394.8 & ${ }^{3} 0.994$ \\
\hline & $y 0$ & 0.9 & 0.1 & $0.7: 1.1$ & ${ }^{4} 0.792$ \\
\hline \multirow{4}{*}{300} & $a$ & 3.1 & 21 & 2.8:3.4 & ${ }^{1} 0.99$ \\
\hline & $b$ & -7.4 & -7.4 & $-9.7:-5.2$ & ${ }^{2} 332.4$ \\
\hline & $x 0$ & 357 & 47 & 340.4:374.1 & ${ }^{3} 0.305$ \\
\hline & $y 0$ & 0.8 & 14 & $0.7: 1.0$ & ${ }^{4} 0.097$ \\
\hline \multirow{4}{*}{350} & $a$ & 3 & 15 & 2.6:3.4 & ${ }^{1} 0.97$ \\
\hline & $b$ & -8.3 & -4.6 & $-12.3:-4.4$ & ${ }^{2} 140.6$ \\
\hline & $x 0$ & 353 & 34 & 329.5:375.7 & ${ }^{3} 0.501$ \\
\hline & $y 0$ & 0.8 & 9.4 & $0.7: 1.0$ & ${ }^{4} 0.457$ \\
\hline \multirow{4}{*}{400} & $a$ & 3.3 & 16 & 2.8:1.0 & ${ }^{1} 0.98$ \\
\hline & $b$ & -6.5 & -6.4 & $-8.7:-4.2$ & ${ }^{2} 223$ \\
\hline & $x 0$ & 368 & 33 & 343.9:392.7 & ${ }^{3} 0.999$ \\
\hline & $y 0$ & 0.8 & 11 & $0.7: 1.0$ & ${ }^{4} 0.163$ \\
\hline
\end{tabular}

${ }^{*} p<0.001$. 
Table 3. Equation of regression and statistical analysis of growth characteristics of rubber tree plants growing under different weed control strips at 360 and 720 days after planting, and of the average relative growth rate (RGR) during two years. Brazil, 2011.

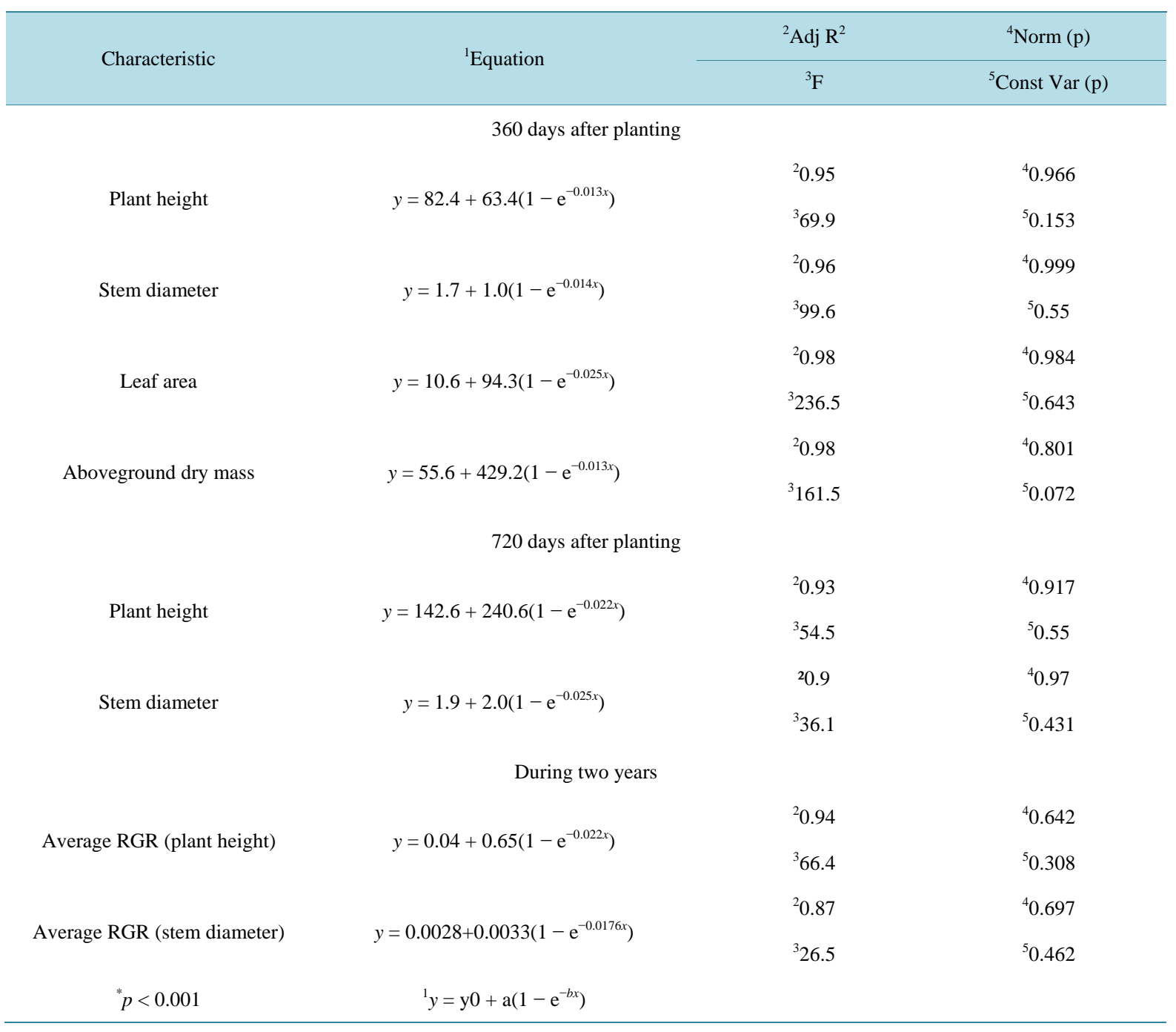

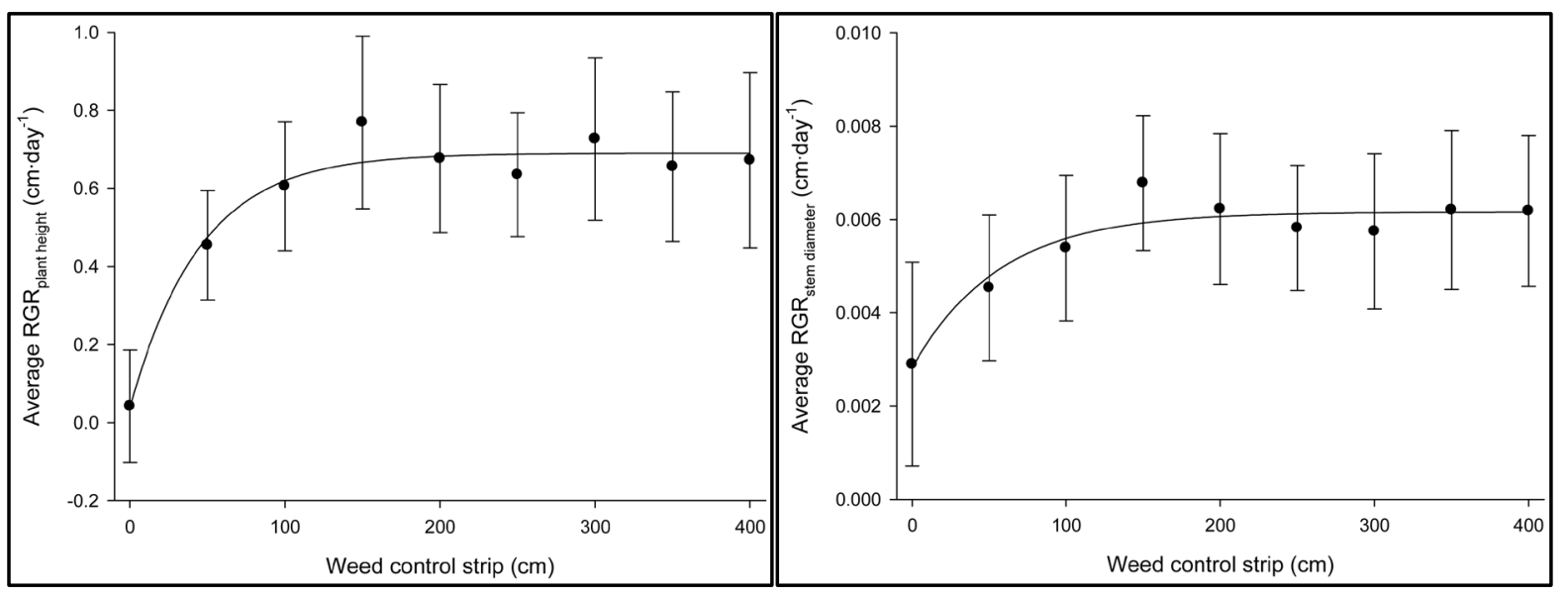

Figure 1. Average of relative growth rate (RGR) based on the plant height and the stem diameter of rubber tree plants growing under different weed control strips during 720 days after planting. Brazil, 2011. 

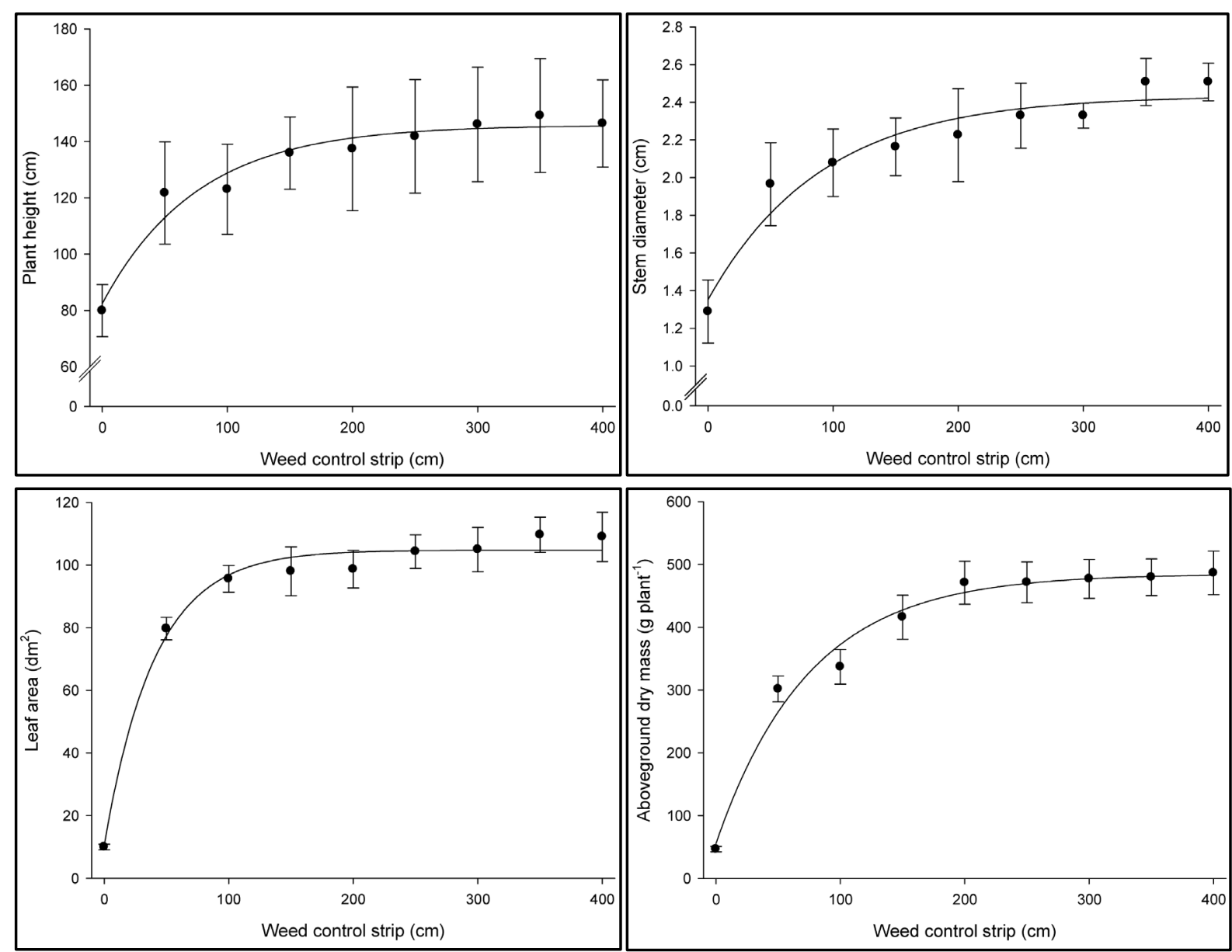

Figure 2. Growth characteristics of rubber tree plants growing under different weed control strips at 360 days after planting. Brazil, 2011.
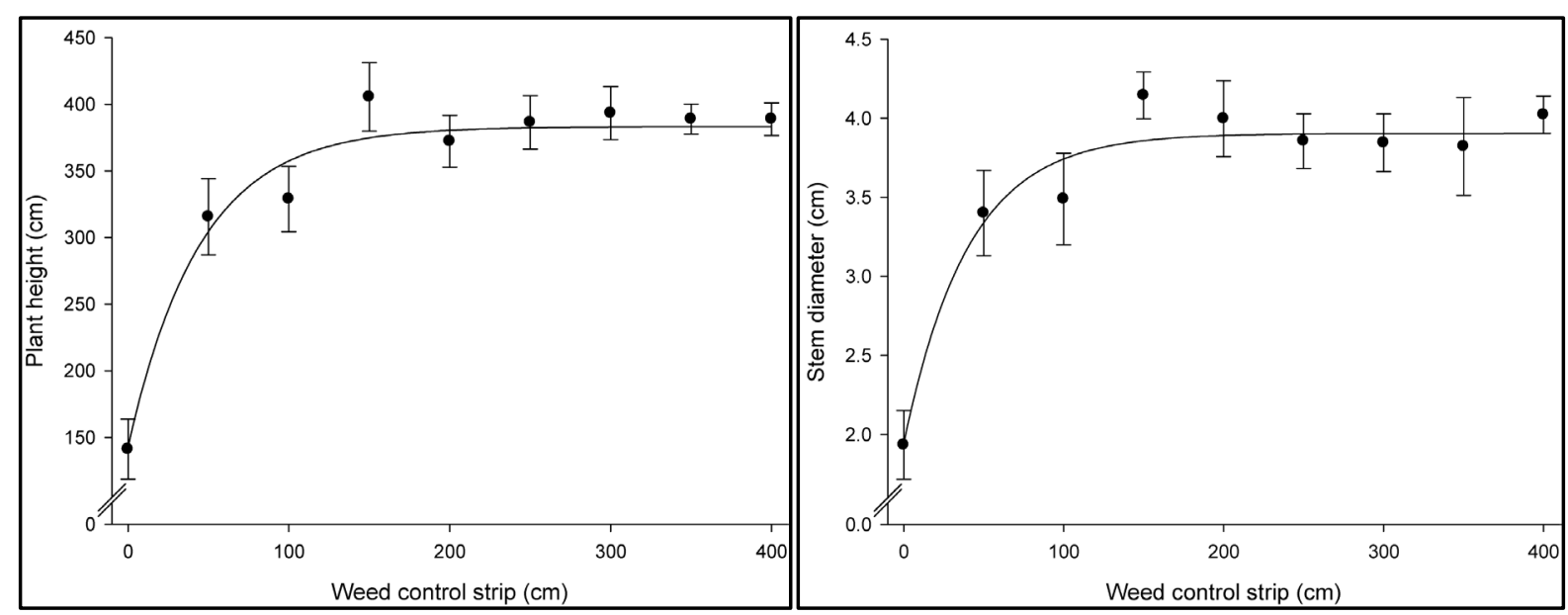

Figure 3. Growth characteristics of rubber tree plants growing under different weed control strips at 720 days after planting. Brazil, 2011.

with weed-free strip width and concluded that a 2-m strip width with no weeding at all in the $1 \mathrm{~m}$ between rows proved to be the best management strategy.

Although trees grown with weed-free strips produced the maximum heights and stem diameters in our expe- 
riment, completely weed-free plantation is rarely necessary for normal tree growth [28]. Such regimes tend to be expensive to maintain in terms of herbicide usage. In addition, lack of ground flora may be deemed to be aesthetically poor and make the soil more susceptible to erosion and leaching [9]. In our experiment, all other inter-row weedy options reduced tree height and stem diameter, but not to an unacceptable degree. However, it is important to control weeds, avoiding competition between plants, until canopy closure begins and trees start to dominate or suppress weed growth [30].

The critical advantage in establishing trees with weed-free areas, compared with no vegetation management, may be that canopy closure may occur several years earlier [9]. This study showed that with an infestation of $U$. decumbens as the main species, it was necessary to have a treated strip of $100 \mathrm{~cm}$ in width to prevent weed interference with the initial growth of $H$. brasiliensis. Toledo et al. [14], studied the width of control strips ( $U$. decumbens as the main weed species) kept during the first 12 months at $0,25,50,100,125$ and $150 \mathrm{~cm}$ on each side of the eucalyptus row and increased these widths throughout the experiment; i.e., 25 to 150, 25 - 50 - 150, 50 - 150, 50 - 125 - 150, 100 - 125 - 150, 100 - 150 and 125 - $150 \mathrm{~cm}$ on each side of the eucalyptus row during the first year. They observed that eucalyptus that had grown both in the constant and increasing-width control strips with widths of at least $100 \mathrm{~cm}$ showed higher diameter, height and absolute growth in diameter and height. These results led the authors to conclude that the minimum control strip width should be $100 \mathrm{~cm}$ on each side of the eucalyptus row to prevent weed interference. In another study, with $U$. decumbens as the main weed species, Toledo et al. [7] verified that it was necessary to have at least $100-\mathrm{cm}$ constant strips or $50-\mathrm{cm}$ increasing control strips to keep eucalyptus plants free of weed interference.

\section{Conclusion}

Taken together, our results allow us to conclude that: 1) the plant growth of rubber trees is affected by a weed community composed mainly by $U$. decumbens growing and interfering on crop establishment, 2) the width of the weed control strip influences on the initial plant growth of rubber trees and, as a consequence, affects the crop plantation. In addition, the intensity of the effect is dependent on the characteristic evaluated, and 3) the critical width of the weed control strip for establishment of a rubber tree plantation is within $100 \mathrm{~cm}$.

\section{Acknowledgements}

Authors thank to CNPq (Master, Research Productivity, and Universal Scholarship Programs) from Brazilian Government and FAPESP (Post-Doc Scholarship Program) from São Paulo State Government, Brazil, for jointly supporting this research.

\section{References}

[1] Feng, S.P., Li, W.G., Huang, H.S., Wang, J.Y. and Wu, Y.T. (2009) Development, Characterization and Cross-Species/Genera Transferability of EST-SSR Markers for Rubber Tree (Hevea brasiliensis). Molecular Breeding, 23, 8597. http://dx.doi.org/10.1007/s11032-008-9216-0

[2] Venkatachalam, P., Thulaseedharan, A. and Raghothama, K. (2009) Molecular Identification and Characterization of a Gene Associated with the Onset of Tapping Panel Dryness (TPD) Syndrome in Rubber Tree (Hevea brasiliensis Muell.) by mRNA Differential Display. Molecular Biotechnology, 41, 42-52. http://dx.doi.org/10.1007/s12033-008-9095-y

[3] IAC-Agronomic Institute of Campinas (2011) Rubber Tree Program. http://www.iac.sp.gov.br/areasdepesquisa/seringueira/importancia.php

[4] Gonçalves, P.S., Bataglia, O.C., Ortolani, A.A. and Fonseca, F.S. (2001) Manual of Rubber Plantation to São Paulo State. IAC, Campinas.

[5] Vollmann, J., Wagentristl, H. and Hartl, W. (2010) The Effects of Simulated Weed Pressure on Early Maturity Soybeans. European Journal of Agronomy, 32, 243-248. http://dx.doi.org/10.1016/j.eja.2010.01.001

[6] Rabbani, N., Bajwa, R. and Javaid, A. (2011) Interference of Five Problematic Weed Species with Rice Growth and Yield. African Journal of Biotechnology, 10, 1854-1862.

[7] Toledo, R.E.B., Victoria Filho, R., Bezutte, A.J., Pitelli, R.A., Alves, P.L.C.A., Valle, C.F. and Alvarenga, S.F. (2003) Brachiaria sp. Free Periods and Effects on the Productivity of Eucalyptus grandis. Scientia Forestalis, 63, 221-232.

[8] Aparicio, P.S., Ferreira, R.L.C., Silva, J.A.A., Rosa, A.C. and Aparício, W.C.S. (2010) Weed Control in Two Clones of Eucalyptus urograndis in Amapá. Ciência Florestal, 20, 381-390.

[9] Silva, J.R.V, Alves, P.L.C.A. and Toledo, R.E.B. (2012) Weed control Strip Influences the Initial Growth of Eucalyp- 
tus grandis. Acta Scientiarum Agronomy, 12, 29-35. http://dx.doi.org/10.4025/actasciagron.v34i1.12252

[10] Garau, A.M., Ghersa, C.M., Lemcoff, J.H. and Barañao, J.J. (2009) Weeds in Eucalyptus globules subsp. Maidenii (F. Muell) Establishment: Effects of Competition on Sapling Growth and Survivorship. New Forests, 37, 251-264. http://dx.doi.org/10.1007/s11056-008-9121-8

[11] Souza, L.S., Losasso, P.H.L., Oshiiwa, M., Garcia, R.R. and Goes Filho, L.A. (2006) Effect of Brachiaria decumbens Control Bands on the Initial Development and Productivity of Coffea arabica. Planta Daninha, 24, 715-720. http://dx.doi.org/10.1590/S0100-83582006000400012

[12] Dias, T.C.S., Alves, P.L.C.A. and Lemes, L.N. (2008) Faixas de controle de plantas daninhas e seus reflexos na produção do cafeeiro. Científica, 36, 81-85.

[13] Araujo, FC., Ronchi, C.P., Almeida, W.L., Silva. M.A.A., Magalhães, C.E.O. and Good-God, P.I.V. (2012) Optimizing the Width of Strip Weeding in Arabica Coffee in Relation to Crop Age. Planta Daninha, 30, 129-138. http://dx.doi.org/10.1590/S0100-83582012000100015

[14] Toledo, R.E.B., Victoria Filho, R., Alves, P.L.C.A., Pitelli, R.A. and Cadini, M.T.D. (2000) Effects of Brachiaria decumbens Strip Control on Eucalypt Initial Plants Development. Planta Daninha, 18, 383-393. http://dx.doi.org/10.1590/S0100-83582000000300001

[15] Knowe S.A., Nelson, L.R., Gjerstad, D.H., Zutter, B.R., Glover, G.R., Minogue, P.J. and Dukes, J.H. (1985) Four-Year Growth and Development of Planted Loblolly Pine on Sites with Competition Control. Southern Journal of Applied Forestry, 9, 11-14.

[16] Boomsma D.B.B. and Hunter, I.R. (1990) Effects of Water, Nutrients and Their Interactions on Tree Growth, and Plantation Forest Management Practices in Australasia: A Review. Forest Ecology and Management, 30, 455-476. http://dx.doi.org/10.1016/0378-1127(90)90154-4

[17] Richardson, B. (1993) Vegetation Management Practices in Plantation Forests in Australia and New Zealand. Canadian Journal of Forest Research, 23, 1989-2005. http://dx.doi.org/10.1139/x93-250

[18] Savill, P., Evans, J., Auclair, D. and Falck, J. (1997) Plantation Silviculture in Europe. Oxford University Press, Oxford.

[19] Adams, P.R., Beadle, C.L., Mendham, N.J. and Smethurst, P.J. (2003) The Impact of Timing and Duration of Grass Control on Growth of a Young Eucalyptus globulus Labill. Plantation. New Forests, 26, 147-165. http://dx.doi.org/10.1023/A:1024490707175

[20] Lewis, N.B. and Ferguson, I.S. (1993) Management of Radiata Pine. Inkata Press, Melbourne.

[21] Waring, H.D. (1972) Pinus Radiata and the Nitrogen-Phosphorus Interaction. In: Boardman, R., Ed., Proceedings of the Australian Forest-Tree Nutrition Conference, Canberra, 6-17 September 1971, Australian Forestry and Timber Bureau, Canberra.

[22] Flinn, D.W., Hopmans, P., Moller, I. and Tregonning, K. (1979) Response of Radiata Pine to Fertilizers Containing N and P Applied at Planting. Australian Forestry, 42, 125-131. http://dx.doi.org/10.1080/00049158.1979.10674214

[23] Nambiar, E.K.S. (1990) Interplay between Nutrients, Water, Root Growth and Productivity in Young Plantations. Forest Ecology and Management, 30, 213-232. http://dx.doi.org/10.1016/0378-1127(90)90138-2

[24] Dias, G.F.S., Alves, P.L.C.A., Dias, T.C.S. (2004) Brachiaria Decumbens Supresses the Initial Growth of Coffea arabica. Scientia Agricola, 61, 579-583. http://dx.doi.org/10.1590/S0103-90162004000600003

[25] Marcolini, L.W., Alves, P.L.C.A., Dias, T.C.S. and Parreira, M.C. (2009) Effect of the Density and of the Distance of Brachiaria Decumbens Staff on the Initial Growth of Coffea arabica L. Seedlings. Coffee Science, 4, 11-15.

[26] Brendolan, R.A., Pellegrini, M.T. and Alves, P.L.C.A. (2000) Effects of Mineral Nutrition on Inter- and Intra-Specific Competition of Eucalyptus grandis and Brachiaria decumbens: 1-Plant Growth. Scientia Forestalis, 58, 49-57.

[27] Davies, R.J. (1987) Tree and Weeds: Control for Successful Tree Establishment. HMSO, London.

[28] Schumann, A.W., Little, K.M. and Snell, C.J. (1994) Recommendations on Establishment Weeding Intensity in Zululand Updated 15-Month Results from Three Competition Trials and Simulation Models. ICFR Bulletin, 3, 1-8.

[29] Little, K., Schumann, A.W., Eccles, N. and Snell, C. (1994) Weed Research, Coppice Management and Old Land Rehabilitation. Annual Research Report, Institute for Commercial Forestry Research (ICFR), South African.

[30] Willoughby, I. and Dewar, J. (1995) The Use of Herbicides in the Forest. HMSO, London. 